\title{
The Desegregation of Public Libraries in the Jim Crow South
}

Wiegand, Wayne A. and Shirley A. Wiegand. The Desegregation of Public Libraries in the Jim Crow South. Baton Rouge, LA: Louisiana State University Press, 2018. 296 pp. \$38.00. Cloth. ISBN: 9780807168677

That desegregation and public library are in the same title should give any reader pause. In this book, the Wiegands write to enlighten the profession's collective memory on the issues of public library integration in the American South. They begin by offering a cursory review of the First Reconstruction (1865-1875), and legislation relating to race enacted during this period. A brief discussion of the Second Reconstruction (1954-1968) follows, ending with the death of Martin Luther King, Jr. Chapter 1 considers libraries in the Jim Crow South before Brown v. Board of Education, while chapter 2 reflects on early integration efforts in this system. The subsequent chapters, 3 through 8, chronicle library integration (with varying degrees of success) across several states in the South. Chapter 9 concludes with a look at the relative inaction of the American Library Association and other professional library associations surrounding issues of desegregation.

The Desegregation of Public Libraries is far-reaching in terms of audience. However, this book seems particularly directed to three distinct groups. The first of these are the protesters whose deeds are documented in these pages. This is evidenced by the dedication: "To the black youths / who risked their lives to desegregate / Jim Crow public libraries." As the Wiegands state later on, "It’s long past time that library organizations and individual libraries do something to recognize the kids-now senior citizens for those who are still alive-who literally risked their lives to integrate libraries” (210). This book is both about them and for them.

Individual librarians and libraries are also intended audiences. The Wiegands suggest that the history of segregated library services remains unknown: “...because most librarians living today do not know the history recorded in these pages” (210). Librarians have largely ingested the misconception that our professional history has always been marked by a defense of intellectual freedom.

Thirdly, this book is directed at the American Library Association, in an almost indictive fashion. The salient call to ownership of their inaction is no minor note in this text. In laying their theoretical framework, the authors qualify the ALA as aloof: “...the American Library Association, which was largely absent and mostly silent about Jim Crow public libraries until well into the 1960s” (17). The indictment holds to the end of the book, chronicling the ALA's complicity in racial discrimination: “...the American Library Association... voted to continue welcoming into membership all libraries, including those that discriminated against black people" (184). The Wiegands also note that the American Library Association did not file an amicus curice brief in Brown v. Louisiana (1966), missing a prime opportunity to demonstrate the profession's ostensible commitment to equity.

In terms of strengths, this title has several. The authors neatly weave the history of public library integration with events of national scale. For instance, those with even a cursory knowledge of the civil rights movement will have heard of Eugene "Bull" Connor's 1962 skirmish with Martin Luther King, Jr. in Birmingham. The Wiegands vivify this picture by highlighting that the day before this encounter, the Birmingham Public Library board quietly desegregated to avoid culpability in the rising violence.

This work also provides information that is heretofore unexamined in information sciences discourse. Patterson Toby Graham's A Right to Read: Segregation and Civil Rights in Alabama's Public Libraries, 19001965 is considered a pre-eminent work in this area, but it only presents the history of a single state. Cheryl Knott's Not Free, Not For All: Public Libraries in the Age of Jim Crow provides a broader scope, but does not emphasize the sit-ins and subsequent violence. This book, however, broadly traces the history of public library desegregation across several states in the South, while examining the local conflict in selected cit- 
ies. The use of variegated resources offers an organic history, as opposed to a mere chronological listing; the authors consult newspapers, manuscript collections, public library annual reports, federal litigation, and Atlanta University master's theses written before 1967. The master's theses are particularly critical as they were written by black library science students under the guidance of Virginia Lacy Jones (the first African-American to earn a PhD in Library Science) and constitute the majority of the profession's research literature on the topic.

Some readers might find it strange, however, to encounter an emphasis on white suffering in a history that is supposed to be about black youths and their agency. There is the story of Ruth Brown, a white library director in Bartlesville, Oklahoma who was fired from her job for attempting to integrate the library in 1950. Following this is the history of Sally Veatch, a white WMAZ radio announcer in Macon, Georgia, who quit her job in 1952 after lamenting over the air that: “...Negroes must plead and demand access to books" (50). The most opportune example is that of Juliette Morgan, a white Montgomery public librarian, who wrote a letter to the Montgomery Advisor in favor of integration. The authors highlight the subsequent backlash, leading to her untimely death. Perhaps, the Wiegands include these stories to vindicate the reputation of white librarians in the Jim Crow South. A more fitting placement might be as an appendix.

This does not completely undermine the authors' objectives. The book centers on the stories of black youths. In an interview that precedes the title page, the authors explain that it was black youths, not necessarily the more famous civil rights personas, who desegregated the public libraries. They sustain this by clearly identifying the names and ages of participants throughout the work. This is especially true in chapter 8 entitled, "Black Youth in Rural Louisiana". A selected list of protestors in the appendix offers further detail, including race, age, and occupational data.

The authors also write to highlight the relative lack of action on the part of the ALA. This is noted throughout, but particuarly accomplished in chapter 9, "The American Library Association”, which highlights the internal discussions surrounding race and segregation from 1876 to the present.

The language is academic but accessible to a wide range of readers. The onslaught of dates and times as presented in each chapter may be difficult to follow, but the astute reader will soon adjust to the Wiegands' precise style. Beyond this, the presentation is logical. Brown v. Board of Education serves as a rough dividing line between chapters 1-2 and 3-8. Chapter 9 is quite helpfully placed. After documenting integration efforts in selected states, the final chapter fills in the missing ALA pieces.

This book strives toward objectivity. There are several instances in which the authors show the constraint of librarians in the Jim Crow South. For example, Lura G. Currier, Director of the Mississippi Library Commission, responds to a request from an African American librarian to establish a Negro library with commission funds. While Currier sends an official refusal for state funds, she also sends a personal letter offering help.

The same is exemplified by the later discussion of the American Library Association and race. In 1899, ALA President William Coolidge Lane sought to address the race issue by inviting W. E. B. Du Bois as a potential speaker for the Atlanta conference. White Atlanta librarians objected, fearing it too polemic. While some might read this as a certain measure of white fragility, the Wiegands expand our thinking by juxtaposing a relevant lynching account: "[Atlanta librarians] had ample reason to be concerned... On April 23 a black man was lynched in nearby Newman... Two thousand people watched, many arriving on a special excursion train from Atlanta. Several in the audience tore the body apart after the victim died" (185-6).

The Desegregation of Public Libraries in the Jim Crow South would make an important addition to libraries across the globe. In an age where some subscribe to the idea that 'libraries don't take sides', this book reminds us that librarians can easily become complicit in larger systems of oppression.

This book can also serve as a guide to new challenges facing libraries-especially those theological libraries attached to conservative institutions. For instance, what can the desegregation of bathrooms in public libraries teach us as we advocate for gender-neutral restrooms and serve as allies to trans folks 
who have bathroom anxiety? In what ways might libraries model equity to their parent institutions (city, state, university, etc.)?

It is imperative that librarians across every discipline know the history contained in these pages. If librarians must take a side-let it be the side of equitable access for all.

Kashif Andrew Graham Outreach Librarian for Religion and Theology

Vanderbilt University

Nashville, TN 